\title{
Diplomatic Dilemma dan Standar Ganda Politik Amerika Serikat Terhadap Konflik Sipil-Militer Mesir Tahun 2013
}

\author{
Azhari Setiawan \\ Pusat Studi Masyarakat ASEAN, Universitas Riau \\ Kampus Bina Widya Simpang baru, Riau 28293 \\ Emauil: azharisetiawan@gmail.com \\ Diterima pada 26 September 2014, Disetujui pada 21 Maret 2015
}

\begin{abstract}
United States of America as the main actor-in many cases_-of world politics constellation has done a number of double standard politics for preserving its certain national interest. For a century, Middle East has been one of the most focussed object for United States foreign policies. This research is aimed to explain United States diplomatic dilemma and double standard politics toward Egypt civil-military conflict and Morsi coup in 2013, which tries to answer why United States used double standard politics on Egypt case. United States never calls Egypt case as a coup and still continuing its foreign aid to Egypt's new governement (military government). Researcher has formulated an answered-hypothesis which reveals the facts that United States double standard is caused by United States diplomatic dilemma. These diplomatic dilemmas also influenced by United States pragmatism on its Arab Spring foreign policy.

Keywords: Diplomatic Dilemma, Double Standard Politics, Coup, United States of America, Arab Spring, Middle East.
\end{abstract}

\begin{abstract}
Abstrak
Amerika Serikat sebagai aktor utama — dalam banyak kasus — pada konstelasi politik dunia telah banyak melakukan politik standar ganda dalam mempertahankan kepentingan nasionalnya. Dalam satu abad, Timur Tengah telah menjadi objek yang paling difokuskan oleh politik luar negeri Amerika Serikat. Tulisan ini ditujukan untuk menjelaskan Dilema Diplomatik yang dialami Amerika Serikat dan Politik Standar Ganda terhadap konflik sipil-militer Mesir dan kudeta terhadap Presiden Morsi pada tahun 2013, yang mana tulisan ini mencoba menjawab mengapa Amerika Serikat menggunakan politik standar ganda pada kasus Mesir. Amerika Serikat tidak pernah menyebut kasus Mesir sebagai sebuah kudeta dan tetap melanjutkan bantuan luar negerinya kepada pemerintahan baru Mesir (pemerintahan militer, Jenderal As Sisi). Penulis telah memformulasikan sebuah hipotesis yang terjawab bahwa ditemukan fakta-fakta yang menunjukkan politik standar ganda Amerika Serikat disebabkan oleh suatu Dilema Diplomatik. Dilema Diplomatik ini juga dipengaruhi oleh pragmatisme Amerika Serikat terhadap politik luar negeri di Arab Spring. Keywords: Dilema Diplomatik, Politik Standar Ganda, Kudeta, Amerika Serikat Arab Spring, Timur Tengah.
\end{abstract}

\section{PENDAHULUAN}

Penelitian ini beranjak pada sebuah pemahaman tentang politik standar ganda yang dilakukan Amerika Serikat terkait dgn pemeliharaan nilai-nilai kemanusiaan dan Hak Asasi Manusia dalam kerangka demokratisasi pada implikasi konflik politik Arab Spring. Amerika Serikat menerapkan standar ganda pada responnya terhadap kasus kudeta militer yang terjadi di Mesir. Kudeta ini dipimpin oleh Menteri
Pertahanan yang juga salah satu dari pimpinan tertinggi SCAF (Supreme Council of the Armed Forces), Jenderal Abdul Fatah As Sisi. As Sisi menggulingkan Mohammed Mursi, selaku presiden pertama Mesir yang dipilih melalui proses demokratis (pemilihan umum).

Pada penghujung 2010 hingga 2011, Timur Tengah mengalami pergolakan politik yang disebut sebagai 
"Arab Spring" atau disebut juga dengan "Jasmine Revolution”. Revolusi ini bertujuan untuk menumbangkan rezim otoriter dan menggantikannya dengan sistem demokrasi. Mesir merupakan salah satu negara yang tidak lepas dari Arab Spring. Revolusi yang diprakarsai oleh Ikhwanul Muslimin sebagai salah satu organisasi politik transnasional berbasis Islam terbesar saat ini telah berhasil menumbangkan penguasa diktator Husni Mubarak yang telah berkuasa selama 30 tahun. Sistem Demokrasi kemudian berdiri setelah lengsernya Husni Mubarak pada tahun 2011 dan dibuktikan dengan pemilihan umum (pemilu) yang memilih Mursi sebagai presiden Mesir sebagai pemimpin yang sah dan demokratis.

Diawal pemerintahan Mursi, stabilitas politik Mesir masih tetap bergejolak. Hal ini ditandai demonstrasi yang setiap hari terjadi, bentrok antara pendukung dan penentang pemerintah, protes-protes terhadap dekrit presiden, dan pelaksanaan referendum. Pada 22 November 2012, Mursi menerbitkan dekrit tentang kekuasaan baru buat dirinya sendiri. Namun, dia membatalkan dekrit itu pada 8 Desember setelah ada penolakan luas. $64 \%$ pemilih dalam referendum dua putaran mendukung konstitusi baru itu dalam sebuah pemungutan suara yang oposisi katakan telah dicurangi. Namun Mahkamah Agung Mesir tidak mengesahkan Senat yang didominasi kaum Islamis, yang mengemban sebuah peran legislatif ketika parlemen dibubarkan, dan sebuah panel yang menyusun konstitus. Hasil ini memicu pro dan kontra antara oposisi dan pendukung Mursi.

Demokrasi yang hanya bediri dalam setahun direngut oleh junta militer. Hal ini jika dipandang dari berbagai sudut tentu saja merupakan penistaan terhadap nilai-nilai demokrasi itu sendiri. Lebih parah lagi, implikasi dari kudeta militer ini berakibat pada jatuhnya ribuan korban penembakan oleh militer Mesir terhadap para demonstran pendukung Morsi.

Spawforth Hornblower dalam The Oxfrod Companion to Classical Civilization menyatakan bahwa kudeta adalah merobohkan legitimasi atau pukulan terhadap negara dengan melalukan tindakan pembalikan kekuasaan terhadap seseorang yang berwenang dengan cara ilegal dan sering kali bersifat brutal, inkonstitusional berupa "pengambil-alihan kekuasaan", "penggulingan kekuasaan” sebuah pemerintahan negara dengan menyerang (strategis, taktis, politis) legitimasi pemerintahan kemudian bermaksud untuk menerima penyerahan kekuasaan dari pemerintahan yang digulingkan.

Samuel P. Huntington merumuskan bahwa terdapat tiga jenis kudeta diantaranya:

- Kudeta Sempalan, dilakukan oleh kelompok bersenjata yang dapat terdiri dari militer atau tentara yang tidak puas dengan kebijakan pemerintahan tradisional saat itu, kemudian melakukan gerakan yang bertujuan untuk menggulingkan pemerintah tradisional dan kemudian menciptakan elit birokrasi baru.

- Kudeta Wali, dilakukan oleh sekelompok pengkudeta yang akan mengumumkan diri sebagai perwalian dalam rangka meningkatkan ketertiban umum, efisiensi, dan mengakhiri korupsi, para pemimpin kudeta akan menggambarkan tindakan mereka hanyalah tindakan sementara dan akan menyesuaikan dengan kebutuhan. Pada umumnya, kudeta wali sering dilakukan dengan cara mengubah bentuk pemerintahan sipil menjadi bentuk pemerintahan militer.

- Kudeta Veto, dilakukan melalui partisipasi dan mobilisasi sosial dari sekelompok massa rakyat dalam melakukan penekanan berskala besar yang berbasis luas pada oposisi sipil

Berdasarkan dua pendapat ahli mengenai definisi kudeta dan jenis-jenis kudeta, dapat dipahami bahwa apa yang terjadi di Mesir adalah sebuah kudeta karena As Sisi dengan terang-terangan melakukan perebutan kekuasaan dan merebut legitimasi kekuasaan yang berada pada Mursi dengan cara yang inskonstitusional. Kemudian, berdasarkan paparan Huntington, Mesir dapat digolongkan kepada jenis kudeta sempalan (Breakthrough Coup).

Mesir adalah negara penerima bantuan dana Amerika Serikat terbesar kedua setelah Israel. Tiap tahunnya, Mesir menerima bantuan dana sebesar 1,5 


\section{METODOLOGI TINJAUAN PUSTAKA}

Penulis menggunakan kerangka dasar teori yang beranjak pada perspektif rasionalisme dalam Hubungan Internasional. Martin Wight sangat menekankan tentang rasionalisme yang mengakui bahwa kondisi anarki memaksa negara untuk mewujudkan keamanan mereka sendiri dan mengakui bahwa gagasan moralitas universal terus memeriksa egoisme tinggi yang terdapat bahkan dalam konteks anarki di mana tidak ada kekuasaan otoritas atau kedaulatan lebih tinggi yang dilengkapi dengan hak resmi untuk memerintah tindakan-tindakan negara. Perspektif ini melihat bagaimana perilaku Amerika Serikat yang dikaji melalui teori keamanan nasional, dihadapkan pada dilema-dilema diplomatik yang terjadi dalam menghadapi kasus di Mesir. Dilema diplomatik ini menghadapkan Amerika Serikat kepada sejumlah pilihan-pilihan dan konsekuensi yang terjadi pada setiap keputusan yang diambil. Teori keamanan nasional dalam kerangka rasionalisme mengantarkan Amerika Serikat pada sebuah keputusan final dimana "standar ganda" dalam politik luar negeri terkait kasus Mesir adalah sebuah pilihan yang rasional bagi Amerika Serikat.

Penelitian ini dibangun atas empat pondasi utama yakni, Perspektif Rasionalisme yang diarahkan oleh Teori Keamanan Nasional dan menggunakan dua konsep utama penelitian, Dilema Diplomatik dan Politik Standar Ganda. Secara teoritik, tiga pondasi utama ini yang nantinya akan menjawab bagaimana politik standar ganda menjadi sebuah pilihan rasional bagi Amerika Serikat dalam membangun stabilitas keamanan nasionalnya (militer dan non-militer) di kawasan Timur Tengah.

Ada beberapa pertimbangan dalam usaha Amerika Serikat untuk mencapai level "aman" jika dihadapkan pada kasus kudeta militer mesir dan fenomena Arab Spring. Pertama, hubungan diplomatik Amerika Serikat terhadap negara-negara aktor kunci lainnya yang ikut ambil tindakan terhadap kasus kudeta militer Mesir. Kedua, tekanan dunia internasional yang mengecam dan mendesak Amerika Serikat untuk ambil tindakan 
setidaknya untuk mencegah bertambahnya korbankorban kudeta yang terus bertambah. Ketiga, kepentingan Amerika Serikat sendiri terhadap Mesir dan segala fenomena yang menyertainya.

Dilema-dilema ini kemudian mengharuskan Amerika Serikat sengaja ataupun tidak disengaja, melakukan politik standar ganda agar kepentingan Amerika Serikat dan faktor-faktor aman yang diperlukan dalam stabilitas politik dan keamanan di Timur Tengah, khususnya Mesir dapat dicapai. Pilihan untuk melakukan standar ganda menjadi pilihan yang rasional bagi Amerika Serikat.

\section{HASIL DAN PEMBAHASAN}

Penelitian ini membuktikan bahwa respon suatu negara terhadap sebuah kasus internasional tidak selalu disebabkan atau dipengaruhi semata oleh motif negara tersebut terhadap konflik. Kompleksnya konstelasi politik keamanan dan/atau ekonomi politik di Timur Tengah banyak mempengaruhi respon Amerika Serikat yang secara historis selalu ambil peran dalam setiap isuisu yang terjadi di Timur Tengah.

Amerika Serikat yang mengalami dilema secara diplomatik dihadapkan pada tindakan negara-negara kunci lain yang juga merupakan sekutu terdekat Amerika Serikat, yang mendukung bahkan memberi bantuan moril dan materil untuk pelaksanaan kudeta militer dan pembentukan pemerintahan baru militer Mesir yang secara konstitusi dan konsensus internasional tentang demokrasi adalah tindakan yang salah dan perlu respon aktif dari dunia internasional.

Namun, yang ditunjukkan oleh Amerika Serikat 180 derajat berbeda dengan respon-respon sebelumnya terhadap tindak kekerasan dan pelanggaran HAM berat di negara-negara kawasan Timur Tengah lainnya. Sebut saja, Libya, Suriah, dan negara-negara Timur Tengah lain yang mengalami permasalahan serupa.

Atas nama demokrasi rakyat sipil Mesir menjalankan demonstrasi berupa aksi damai menentang pelecehan demokrasi dan nilai-nilai kemanusiaan oleh militer Mesir. Hasilnya, ribuan rakyat sipil Mesir mengalami penembakan oleh militer Mesir dan ini merupakan pelanggaran HAM berat terbesar setelah Libya. Selain hak kemanusiaan untuk hidup, di Mesir juga terjadi pelanggaran hak politik berat yang dialami oleh presiden terpilih secara demokratis, Mohamed Morsi.

Amerika Serikat yang sebelumnya "garang" untuk memberantas kejahatan kemanusiaan di Arab Spring kini terkesan "menutup mata telinga" pada kasus Mesir. Secara nyata Presiden Obama menyatakan dengan gamblang bahwa Amerika Serikat tidak bisa menentukan masa depan Mesir dan secara tersirat juga mengatakan bahwa apa yang terjadi di Mesir bukanlah sebuah kudeta. Amerika Serikat menyatakan bahwa pelengseran secara paksa oleh militer karena alasanalasan politis terhadap seorang presiden yang terpilih secara demokratis dianggap tidak termasuk dalam kategori kudeta, tidak termasuk dalam pelecehan demokrasi.

Kesekian kalinya, Amerika Serikat melakukan politik standar ganda terhadap kasus pelanggaran HAM berat yang terjadi di Mesir. Ribuan korban yang tidak bersalah dan puluhan ribu rakyat sipil Mesir yang ditahan tanpa alasan hukum yang kuat dan jelas tidak menjadi penghalang bagi Amerika Serikat untuk terus tetap memberikan bantuan kepada pemerintahan baru Mesir yang diambil alih oleh Jenderal As Sisi. Selain itu, Amerika Serikat yang tidak tegas di Mesir justru sangat aktif untuk terus mencegah dan menanggulangi kasus HAM berat di negara lain seperti Suriah dimana Amerika Serikat terus mempromosikan kepada dunia internasional untuk ikut berperan aktif memerangi otoriterisme di Suriah.

\section{DILEMA DIPLOMATIK AMERIKA SERIKAT TERHADAP KONFLIK SIPIL-MILITER MESIR}

Ada beberapa situasi yang menjadi bahan pertimbangan yang dilematis bagi Amerika Serikat. Dilema tersebut antara lain ialah: jumlah korban yang melebihi angka seribu dimana berdasarkan pada klasifikasi konflik, konflik ini sudah mencapai level konflik tingkat tinggi dan menyentuh ranah kasus HAM berat. Amerika Serikat adalah "kesatria" demokrasi dan HAM yang selalu turun tangan di belahan dunia manapun. Kedua, tanggapan negara- 
negara sekutu terdekat Amerika Serikat seperti Arab Saudi dan Uni Emirat Arab yang justru mendukung kudeta militer dan "pembantaian" rakyat sipil yang dilakukan oleh pemerintah lewat militer.

Pertimbangan selanjutya adalah hubungan diplomatik Amerika Serikat dengan pemerintahan Mesir sebelum Mursi, dan pada masa Mursi yang memiliki perbedaan dari segi ideologi, dan arah kebijakan luar negeri. Selanjutnya pertimbangan terakhir adalah adanya indikasi bahwa kudeta militer terhadap Mursi tidak murni sebagai keinginan rakyat namun terdapat indikasi bahwa kudeta ini dirancang oleh pihak-pihak oposisi bersama aktor-aktor eksternal.

Ketika berbicara mengenai dilema diplomatik, maka yang menjadi bahan pertimbangan ialah dengan merujuk pada sekutu-sekutu terdekat Amerika Serikat yang secara politik juga ikut berkepentingan terhadap kasus Mesir. Secara politik diplomatik, sikap dan respon negara-negara sekutu Amerika Serikat terkait kasus Mesir akan memberikan pengaruh tersendiri bagi sikap dan respon Amerika Serikat.

Terjalinnya hubungan diplomatik pada tingkat aliansi atau sekutu antara Amerika Serikat dan sejumlah negara-negara Timur Tengah menduduki pos tersendiri dalam agenda politik luar negeri Amerika Serikat di Timur Tengah diantaranya adalah agenda demokratisasi serta stabilisasi keamanan dan pengaruh Amerika Serikat di Timur Tengah. Di satu sisi, Amerika Serikat berkepentingan menyebarkan demokrasi ke Timur Tengah, namun, di sisi lain, Amerika Serikat juga berkepentingan mengendalikan perpolitikan di Timur Tengah terutama melalui negaranegara sekutunya tersebut.

Senada dengan pernyataan Albertine Minderop dalam "Pragmatisme Sikap Hidup dan Prinsip Politik Luar Negeri Amerika Serikat" yang menyatakan bahwa, masuknya Amerika Serikat dalam konstelasi politik regonal Timur Tengah sudah dapat dirasakan sejak pasca Perang Dunia ke-2 di Iran dimana pada saat itu situasi politik internal Iran sedang mengalami gejolak persaingan antara Shah Mohammed Reza Pahlevi dan koalisi nasionalis Iran yang bermaksud mengurangi pengaruh asing terhadap sumber daya alam dan kelembagaan pemerintah mereka dengan tuntutan menasionalisasikan aset Anglo Iranian Company milik Inggris.

Selain untuk menyebarkan demokratisasi, Amerika Serikat juga ingin mempertahankan pengaruhnya di Timur Tengah untuk membendung pengaruh dari Uni Soviet-saat ini Rusia-yang juga mencoba masuk ke Timur Tengah. Amerika Serikat pada masa Reagan banyak menjalin hubungan dengan negara-negara seperti Mesir, Israel, Jordania, dan Arab Saudi untuk melancarkan agendanya. Metode yang digunakan Amerika Serikat pun bermacam-macam, dimulai dari pemberian bantuan luar negeri baik ekonomi dan/atau militer, hingga menjalin persekutuan atau aliansi.

Dukungan-dukungan sekutu Amerika Serikat terhadap kudeta militer yang dilakukan As-Sisi secara langsung memberikan sinyal kepada Amerika Serikat untuk mengikuti sikap dari para sekutunya. Pengaruh dukungan-dukungan ini terletak pada hubungan diplomatik Amerika Serikat terhadap negara-negara sekutunya tersebut. Kemungkinan membaik atau memburuknya hubungan Amerika Serikat dengan negara-negara sekutunya tersebut ditentukan oleh respon Amerika Serikat sendiri terhadap kudeta.

Berdasarkan sejarahnya, sekutu-sekutu Amerika Serikat seperti Arab Saudi, Uni Emirat Arab, Israel, dan Mesir sendiri telah banyak memberikan kemudahan-kemudahan bagi Amerika Serikat baik secara ekonomi-politik lewat tambang dan perdagangan minyak serta militer lewat izin membangun pangkalan militer Amerika Serikat di sejumlah titik strategis negara-negara ini.

Analisis yang dapat dilihat dari fenomena ini adalah ada beberapa kemungkinan yang terjadi jika Amerika Serikat tidak mengikuti keinginan para negara sekutunya yang mendukung kudeta antara lain: (1) memburuknya hubungan Amerika Serikat dengan negara-negara sekutu di Timur Tengah yang mendukung kudeta karena dinilai sudah tidak memiliki kesepahaman lagi dalam menanggapi isu kudeta di Mesir; (2) kemungkinan berkurangnya kemudahan-kemudahan yang diberikan negara sekutu kepada Amerika Serikat dalam menjalankan agenda 
demokratisasi di Timur Tengah karena Amerika Serikat dianggap tidak mendukung sikap negara sekutu; dan (3) terancamnya kepentingan ekonomi politik Amerika Serikat di Timur Tengah-khususnya di bidang pertambangan minyak-jika tidak mengindahkan sikap para negara sekutu yang mendukung kudeta. Dilemadilema inilah yang melatarbelakangi Amerika Serikat melakukan politik standar ganda terhadap kasus kudeta militer di Mesir.

Hal lain yang menjadi pertimbangan bagi Amerika Serikat untuk menyatakan sikapnya terhadap kasus Mesir adalah jumlah korban jiwa yang sudah mengisyaratkan keharusan respon dan perhatian serius dari dunia internasional dalam bentuk perlindungan kemanusiaan. World Conflict and Human Right Map 2001/2002 oleh PIOOM mengklasifikasikan tingkatan konflik berbanding lurus dengan legitimasi dari pihak internasional untuk memberikan respon. PIOOM mencatat bahwa konflik terbagi atas 5 tingkatan antara lain:

- Situasi Damai dan Stabil: Legitimasi pemerintah tinggi

- Ketegangan Politik: Meleburnya gap sosial dan politik antara faksi-faksi yang ada di masyarakat.

- Kekerasan Politik: 100 Korban/tahun

- Konflik Skala Rendah: 100-999 Korban/tahun (termasuk dalam konflik terbuka/bersenjata)

- Konflik Tingkat Tinggi: >1000 (Perlunya perhatian dunia internasional, dan sudah terjadi perpindahan penduduk sipil dalam jumlah yang besar)

Jumlah korban Mesir yang telah mencapai angka 3000 lebih sudah mengharuskan perlunya respon dan perhatian dari pihak internasional. Setidaknya negaranegara besar sudah bisa mengajukan proposal Responsibility to Protect atau intervensi non-militer lewat PBB. Hal ini ditujukan untuk mencegah berlarut-larutnya konflik dan bertambahnya korban jiwa.

Selain itu juga, kedekatan Amerika Serikat dengan pihak-pihak militer Mesir yang telah lama "berkuasa" di Mesir menjadi salah satu faktor yang membuat Amerika Serikat mengalami dilema diplomatik. Amerika Serikat telah sangat lama menjalin hubungan diplomatik yang erat dengan pemerintah Mesir era perwira militer. Peran Amerika Serikat sendiri dalam kedekatannya dengan militer Mesir terdiri atas: bantuan dana dimana Mesir adalah negara terbesar kedua penerima bantuan Amerika Serikat sebanyak US\$ 1,5 Miliar/tahunnya; Latihan Militer Bersama yang secara berkala terus dilakukan kedua negara; Adanya program Military Assistance dari Amerika Serikat khusus untuk militer Mesir; dan berbagai kedekatan politik lainnya. Secara langsung maupun tidak langsung, Amerika Serikat telah melahirkan sebuah Republik Para Perwira di tubuh pemerintahan Mesir.

Berdasarkan pemaparan penulis sebelumnya terkait dengan poin-poin strategis yang menjadi bahan pertimbangan Amerika Serikat atas dilema diplomatiknya dalam menyikapi dan mengambil tindakan atas kasus HAM berat di Mesir, maka penulis telah merumuskan sejumlah kondisi dilematis Amerika Serikat beserta segala pilihan-pilihan kebijakan yang memungkinkan untuk diambil oleh pemerintah Amerika Serikat. Poin-poin tersebut antara lain:

Kudeta atau Bukan? Sekutu terdekat AS sebagai aktor kunci kasus Mesir mengakui dan mendukung kudeta yang dilakukan terhadap Mursi di saat Amerika Serikat seharusnya tidak mengakui dan menolak terjadinya kudeta. Amerika Serikat berada pada posisi dimana Amerika Serikat harus menentukan apakah yang terjadi di Mesir merupakan sebuah kudeta atau bukan. Sikap dari para sekutu Amerika Serikat setidaknya telah mempengaruhi sikap dan tindakan Amerika Serikat sendiri.

Jika Amerika Serikat menganggap ini adalah Kudeta, maka otomatis segala bantuan dana dan logistik akan diberhentikan, maka Amerika Serikat akan kehilangan pengaruh moneternya di Mesir. namun jika Amerika Serikat tidak mengaanggap kasus ini sebagai kudeta, maka Amerika Serikat akan terlepas dari segala kewajiban terhadap kasus HAM di Mesir

Desakan Dunia Internasinoal. Varietas respon aktor internasional lain terhadap kasus kudeta militer Mesir dimulai dari yang mendukung, menolak, hingga 
mendesak tindakan Amerika Serikat. Amerika harus mengikuti kepentingan nasionalnya atau mengikuti desakan dunia internasional

Korban Jiwa. Konflik sipil-militer Mesir menurut perkembangan terkahir telah Mencapai angka 3000 lebih (hingga tanggal 31 Januari 2014) dan hingga Oktober 2014 telah mencapai angka 49 ribu lebih korban jiwa. Menurut sejarahnya, Amerika Serikat selalu menggunakan banyaknya korban jiwa sebagai landasan untuk mengambil tindakan. Kasus Libya dapat dijadikan sebagai contoh dimana korban jiwa yang mencapai 40 ribu lebih menjadi parameter diberlakukannya Resolusi R2P Dewan Keamanan PBB yang dimandatkan ke NATO. Amerika Serikat memiliki dua pilihan kebijakan untuk kasus ini, mengusulkan intervensi atas dasar perlunya perhatian pihak internasional atau tidak.

Kedekatan Amerika Serikat dengan Militer Mesir pra dan pasca pemerintahan Mursi mengakibatkan dilema bagi Amerika Serikat. Apakah harus mendukung "rekan" lamanya, atau mendukung pemerintahan demokratis pertama Mesir lewat Mursi.

\section{POLITIK STANDAR GANDA AMERIKA SERIKAT TERHADAP KONFLIK SIPIL-MILITER MESIR}

Korban tewas rakyat sipil yang diakibatkan pada Arab Spring mencapai angka ribuan. Sedangkan tanggapan dari Dunia Internasional khususnya Liga Arab hanya terpaku pada "mengecam" pelanggaran HAM berat yang terjadi. Banyaknya korban tewas menjadi harga mati yang harus dibayar dalam mewujudkan reformasi dan demokratisasi di Timur Tengah. Begitu juga dengan apa yang terjadi di Mesir.

Terkait kasus Mesir ini, Amerika Serikat mengalami kondisi yang berbeda dimana saat menghadapi konflik Libya, Suriah, dan lain-lain tujuan sangat jelas yaitu menegakkan demokrasi dan penegakan HAM serta penghapusan kekuasaan diktator di negara-negara Timur Tengah. Namun, di Mesir tujuan-tujuan ini terhambat oleh hubungan diplomatik Amerika Serikat sendiri dengan negara Timur Tengah lainnya (Arab Saudi, Uni Emirat Arab, dan Israel) yang juga merupakan aktor kunci dalam konflik ini.
Permulaan Arab Spring di Mesir membawa pesan yang bercampur dari pemerintahan Obama, yang mana pertama sekali Obama memberikan dukungan penuh kepada rezim Mubarak, kemudian, dukungan berpindah kepada demontran atau protesters yang ingin menurunkan Mubarak. Namun, pada tahun 2013, setelah Mursi dilengserkan lagi oleh "sisa-sisa pewaris" Mubarak, juga lewat aksi demonstrasi dan ditambah dengan kudeta oleh Militer Mesir, Amerika Serikat lewat Hillary Clinton bahkan mengatakan bahwa Mesir berada dalam keadaan yang stabil. Presiden Obama bahkan menyerukan reformasi dan transisi untuk sesegera mungkin dijalankan. Amerika Serikat seperti menutup mata kepada implikasi dari kudeta militer yang bahkan tidak diakui oleh Ameria sendiri.

Berdasarkan pada pemahaman dan analisis kerangka teoritis yang telah dipaparkan, jawaban atas pertanyaan tentang dilema Amerika Serikat terhadap konflik internal dan pelanggaran HAM berat di Mesir ialah Amerika Serikat tidak melakukan bahkan tidak mengusulkan kasus HAM berat di Mesir untuk diinternasionalisasikan dan diintervensi baik militer maupun non-militer. Pengaruh yang kuat dari Arab Saudi, Uni Emirat Arab dan Israel dalam kasus Mesir ternyata memberikan dilema diplomatik yang cukup kompleks bagi Amerika Serikat sehingga standar ganda menjadi satu-satunya kebijakan yang dinilai rasional bagi Amerika Serikat.

Kebijakan rasional pertama bagi Amerika Serikat ialah dalam setiap pernyataan politiknya, Amerika Serikat, baik lewat Menteri Luar Negerinya, ataupun lewat Presiden Obama sendiri tidak pernah menyebutkan kata "Kudeta" jika berbicara mengenai masalah di Mesir. Amerika Serikat tidak mengakui adanya kudeta di Mesir. Logikanya, jika merumuskan apakah yang terjadi di Mesir kudeta atau bukan tidak mencapi konsensus, maka dengan ini Amerika Serikat tidak harus mendukung atau menolak kudeta itu sendiri.

Jika mengecam adalah sikap dan tindakan Amerika Serikat terhadap Mesir, maka Amerika Serikat juga tidak bisa (atau lebih tepatnya tidak perlu) pusingpusing menyatakan sikap dan tindakan terhadap 
korban jiwa yang telah banyak berjatuhan di Mesir. Perbedaan sikap yang ditunjukkan Amerika Serikat dalam menghadapi kasus-kasus di Arab Spring yang notabene memiliki kriteria permasalahan yang sama (konflik antara pemerintah yang diwakili militer vs rakyat sipil) menyimpulkan sebuah asumsi yang kuat bahwa Amerika Serikat menerapkan politik standar ganda di Arab Spring. Khusus pada kasus ini, politik standar ganda Amerika Serikat di Mesir sangat dipengaruhi oleh dilema diplomatik yang dihadapi oleh Amerika Serikat sendiri.

Sekertaris Gedung Putih, Jay Carney menyatakan, "US is 'cautiously encouraged by the announcement by the interim government it has a potential plan for moving forward with a democratic purpose' and declares that the best hope for resolving the crisis is through an inclusive political process. Ini berarti bahwa pemerintahan sementara bentukan militer bersifat demokratis dan harus dilanjutkan dengan proses politik yang inklusif. Pertanyaannya ialah bagaimana bisa kudeta militer yang sangat dekat dengan keotoriteran membentuk pemerintahan sementara yang demokratis?

Dilanjutkan dengan catatan publikasi statement John Kerry pada 14 Agustus 2013 mengatakan: "United States is strongly condemns" violence in Egypt and urges the government to respect the rights of free assembly and free expression. He lists amending the constitution and holding parliamentary as well as presidential elections as constructive options for an inclusive and peaceful political process".

Amerika Serikat mendukung pemilu untuk dilaksanakan secara segera dan meminta pemerintah Mesir untuk dihargai atas nama majelis yang bebas dan kebebasan berekspresi. Ini berarti bahwa Amerika Serikat secara tidak langsung mendukung terjadinya kudeta militer yang mendesak pergantian Presiden Morsi.

Selanjutnya, catatan GCRP tentang tindakan Amerika Serikat, pada 15 Agustus 2013 sebagai berikut: US Secretary of Defense Chuck Hagel issues a press statement noting that the US will "continue to maintain a military relationship with Egypt" but "violence and inadequate steps towards reconciliation are putting important elements of our longstanding defense cooperation at risk".
Amerika serikat tetap mempertahankan hubungan militer bersama pemerintahan bentukan kudeta militer Mesir. Hal ini tidak sesuai dengan pernyataan Presiden Obama yang menyatakan Amerika Serikat membatalkan latihan militer bersama dengan Mesir pasca kudeta.

Selain itu, penulis juga mengutip tiga kalimat kunci pada pernyataan Presiden Amerika Serikat Barrack Husein Obama setelah berdiskusi dengan US National Security Team pada 15 Agustus 2013 di Press Statement Gedung Putih, yang mengarahkan pada kebijakan luar negeri Amerika Serikat terhadap krisis Mesir antara lain:

"...calls on all parties to work together to address the legitimate grievances of the Egyptian people, in accordance with the democratic process...."

"...on the Egyptian military to move quickly and responsibly to return full authority back to a democratically elected civilian government as soon as possible through an inclusive and transparent process."

"....his government was not inclusive, and do not respect the view of all egyptians, we know that, many of egyptians, millions of egyptions..."

".... America can not determine the future of Egypt, that's the test for Egyptian people, we don't take side with any particular party, or political figure.."

"...to ensure that the rights of all Egyptian men and women are protected, including the right to peaceful assembly, due process, and free and fair trials in civilian courts."

Berdasarkan sejumlah pernyataan tersebut, penulis mendapatkan sejumlah pemahaman antara lain:

Pernyataan pertama jelas memperlihatkan bahwa Amerika Serikat tidak mendukung pihak manapun baik indidvidu ataupun politik, dan mengharapkan segala yang terjadi di Mesir harus dijalankan sesuai dengan proses politik.

Kutipan pernyataan kedua, ketiga, dan keempat Obama dapat dipahami mengandung dua arti. Pertama, Lengsernya Morsi bukanlah sebuah Kudeta. Kedua, Tidak ada penyalahan atas apa yang dilakukan pihak militer Mesir atas pelengseran Presiden Morsi. 
Pernyataan kedua Presiden Obama menjelaskan bahwa apa yang dilakukan oleh pihak militer Mesir adalah sebuah Decision Making Body, yaitu merupakan bagian dari pengambilan kebijakan internal Mesir. Hal yang sangat berbeda sekali dengan apa yang ditunjukkan Amerika Serikat terhadap kasus Libya dan Suriah terkait kekerasan pemerintah terhadap warga sipil.

Pernyataan ketiga menunjukkan perhatian Amerika Serikat terhadap rakyat sipil Mesir pasca pelengseran Presiden Morsi dan pelaksanaan proses pembangunan pemerintahan sesuai dengan prosedur yang demokratis. Namun hingga saat ini kekerasan masih terjadi dan pemerintah Amerika Serikat tidak menanggapi dengan serius terhadap kekerasan tersebut.

Sikap Amerika Serikat yang telah penulis paparkan sangat berbeda sekali dengan sikap negara-negara lain seperti Turkey, Malaysia, Qatar, Tunisia, yang mengecam kekerasan di Mesir serta dukungan terhadap Presiden Morsi sebagai Presiden yang tetap berkuasa. Selain itu juga kumpulan dari berbagai organisasi internasional di Malaysia, Asia Tenggara telah mengeluarkan sebuah deklarasi yang disebut dengan "KUALA LUMPUR DECLARATION ON THE EGYPT COUP” pada 30 Agustus 2013 yang menyatakan bahwa Rakyat Malaysia menolak menyebut demonstran anti pemerintahan militer sebagai teroris dan mengecam keras kudeta yang dilakukan oleh militer Mesir.

Bahkan, Rakyat Malaysia juga menyatakan dalam deklarasi tersebut bahwa Rakyat Malaysia sangat kecewa dan marah atas tindakan Amerika Serikat yang dinilai bungkam terhadap kasus yang terjadi dan berpendapat bahwa tindakan Amerika Serikat yang bungkam memiliki hubungan dengan hubungan antara Amerika Serikat dan Israel sesuai dengan Perjanjian Camp David 1978 dimana Amerika Serikat sangat melindungi keselamatan dan keamanan Israel yang notabene juga mendukung dilakukannya kudeta di Mesir.

Di lain pihak, Arab Saudi, Israel, dan Uni Emirat Arab yang notabene merupakan "sekutu dekat" Amerika Serikat sangat mendukung kudeta militer yang dilakukan di Mesir. Dukungan tidak hanya berbentuk moril namun juga materil. UEA memberikan bantuan sebesar 3 miliar dollar AS kepada pemerintahan interim Mesir. Arab Saudi juga memberikan bantuan materil sebesar 5 miliar dollar untuk pemerintahan militer Mesir dan mengeluarkan fatwa bahwa para pemrotes dan demonstran menentang militer Mesir sebagai teroris dan kaum khwarij. Berbagai sumber menyatakan bahwa peluru yang ditemukan pada korban penembakan di Mesir adalah peluru "dum-dum bullets" buatan Israel menunjukkan adanya tangan asing yang bermain di krisis internal Mesir.

Amerika Serikat pada kasus Mesir dinilai tidak "segarang" pada kasus-kasus HAM ataupun kasus-kasus Arab Spring yang lain layaknya di Libya dan Suriah yang terus mendesak dihentikannya kekerasan bahkan tindakan yang dilakukan berupa ancaman intervensi militer. Pada kasus Mesir, Amerika Serikat bahkan menilai bahwa apa yang dilakukan militer Mesir bukanlah sebuah kudeta dan berarti tidak mencoreng nama demokrasi sehingga "Sang Kesatria Demokrasi" pun tidak perlu turun tangan. Terkait dengan kasus kekerasan terhadap demonstran, Amerika Serikat hanya bertindak pada batas "Strongly Condemn" atau kecaman saja. Kecaman tentu tidak akan berarti apaapa bagi penegakan nilai-nilai kemanusiaan di Mesir pasca kudeta militer.

\section{KESIMPULAN}

Berbeda dengan kasus Palestina, Sudan, Bosnia, dan lain-lain, standar ganda politik Amerika Serikat di Mesir tidak semata hanya disebabkan oleh pragmatisme dari Amerika Serikat saja. Ada sejenis "kegalauan" dari Amerika Serikat sendiri dalam melihat dan merumuskan kebijakan dan langkah yang tepat dalam menghadapi desakan internasional dan kondisi internal Amerika Serikat sendiri terhadap kasus Mesir. Kegalauan ini secara teoritis penulis sebut sebagai "Dilema Diplomatik".

Simpulan dari penelitian ini adalah dilema diplomatik yang dihadapi oleh Amerika Serikat telah mendorong Amerika Serikat untuk melakukan standar ganda pada kasus Mesir. Dilema yang dialami Amerika 
Serikat juga tidak hanya datang dari kondisi eksternal namun juga kondisi internal Amerika sendiri dimana masalah perekonomian, hutang, dan perumusan anggaran Amerika Serikat mengharuskan Amerika Serikat memotong bantuan luar negerinya kepada pemerintahan para perwira Mesir. Meskipun bantuan luar negeri telah dipotong, tetap saja predikat standar ganda tidak bisa dilepaskan karena Amerika Serikat masih tidak ingin mengakui bahwa kasus Mesir merupakan sebuah kudeta dan Amerika Serikat juga mengakui As Sisi secara demokratis adalah presiden yang sah.

Demikianlah penelitian ini telah menjelaskan konseptualisasi teori keamanan nasional dari sudut pandang rasionalisme dalam membangun dilema diplomatik dan politik standar ganda sebagai konsep yang korelatif. Korelasinya dibuktikan dengan sikap dan tindakan yang ditunjukkan oleh Amerika Serikat dalam menghadapi kasus sipil-militer di Mesir pasca kudeta Mursi. Dilema diplomatik dibuktikan telah mendorong Amerika Serikat melakukan standar ganda. Rasionalitas Amerika Serikat dalam membangun stabilitas keamanannya di Timur Tengah lewat Mesir menjadikan standar ganda sebagai pilihan kebijakan yang rasional dan dinilai mampu mengakomodir kepentingan Amerika Serikat pada kasus ini.

\section{BIBLIOGRAFI}

Jurnal, Working Papers, dan Artikel Ilmiah

Anggoro, Kusnanto. 1987. Suatu Pendekatan Holistik ke Arah Teori Keamanan Nasional, Jurnal Ilmu Politik 2. Gramedia, Jakarta.

Banerjee, Stuti. 2013. US Reactions to Developments in Egypt. New Delhi: Indian Council of Wolrd Affair.

Chomsky, Avram Noam. "ãä íPÝ æÑÇÁ ÇáÇäPáÇÈ ÇáãÕ̃̃̃í" (Who's Behind Egypt Coup?) 7\&News_ID=34318"http:// www.egyptwindow.net/news_Details.aspx?Kind=7HYPERLINK "http://www.egyptwindow.net/ news_Details.aspx?Kind=7\&News_ID=34318"\&HYPERLINK "http:/ /mww.egyptwindow.net/

news_Details.aspx?Kind $=7 \&$ News_ID $=34318^{\prime \prime N}$ News_ID $=34318$ diakses pada 26 Oktober 2014 pukul 15.47 WIB.

Cornell University Law School Legal Information Institute. "22 USC § 8422 - Authorization of assistance" http://www.law.cornell.edu/ uscode/text/22/8422 diakses pada 26 Oktober 2014 pukul 13.56 WIB.

Dorsey, James M.. 2013. The US Bogeyman in Post-coup Egypt. Singapura: S. Raja Ratnam School of International Studies.

Dunne, Michelle \& Williamson, Scott. Egypt's Unprecedented Instability by the Numbers. Carnegie Endowment. http:// carnegieendowment.org/2014/03/24/egypt-s-unprecedentedinstability-by-numbers/h5j3 diakses pada 23 Oktober 2014 pukul 23.01 WIB.

Fraser, Suzan. 2013. Erdogan: Israel Behind Egyptian President Mohammed Morsi's Ouster. Diakses dari http:// www.huffingtonpost.com/2013/08/20/erdogan-israelegypt_n_3784716.html pada 23 Oktober 2014 pukul 21.40 WIB

Glaser, Charles E.. 2010. Rational Theory of International Politics: The Logic of Competition and Cooperation. New Jersey: Princeton University Press.

Hassan, Bahey Eldin. 2012. Arab Spring: A Struggle of Three Fronts.

Kahler, Miles. 1998. Rationality in International Relations. Chicago: University of Chicago Press.

Mekay, Emad. Did US funds help oust Morsi? Al Jazeera. http:// www.aljazeera.com/programmes/insidestory/2013/07/ 201371392855688681.html Diakses pada 26 Oktober 2014 pukul 16.41 WIB.

Mekay, Emad. Exclusive: US bankrolled anti-Morsi Activists, Documents reveal US money trail to Egyptian groups that pressed for president's removal. Aljazeera. http://www.aljazeera.com/indepth/ features/2013/07/2013710113522489801.html diakses pada 28 Oktober 2014 pukul 23.40

Michele Dunne; Scott Williamson. 2014. Egypt's Instability by the Numbers. Washington: Carnegie Endowment. Dapat diakses di http://carnegieendowment.org/2014/03/24/egypt-s-unprecedented-instability-by-numbers/h5j4.

Panke, Diana. 2004. How to Combine Rationalist and Constructivist Account on International Politics. Berlin: Center for European Studies Otto-Suhr-Institute.

Pelletreau, Robert H. (24 February 2011). "Transformation in the Middle East: Comparing the Uprisings in Tunisia, Egypt and Bahrain". Foreign Affairs terdapat di: http:// www.foreignaffairs.com/articles/67546/robert-h-pelletreau/ transformation-in-the-middle-east diakses pada 18 Maret 2014 pukul 22.05 WIB

PIOOM. 2002. World Conflict and Human Right Map 2001/2002 diakses dari http://www.standeyo.com/NEWS/09_World/ 090210.world_conf_map.pdf pada 23 Oktober 2014 pukul 22.49. WIB

Rofiq Kurniawan. 2004. Strategi Keamanan Amerika Serikat dalam Merespon Ancaman Senjata Biologi dari Rogue State dan Terrorist Group, (1997-2003), dalam Jurnal Ilmu Hubungan Internasional Antar Bangsa, Fakultas IImu Sosial dan IImu Politik Universitas Riau, 2004. Vol. 2. No. 1. 1 Januari.

Werr, Patrick. 2013. UAE offers Egypt $\$ 3$ billion support, Saudis $\$ 5$ billion. REUTERS. Diakses dari http://www.reuters.com/article/2013/ 07/09/us-egypt-protests-loan-idUSBRE9680H020130709. Pada 23 Oktober 2014 pukul 20.00 WIB

\section{BUKU}

Abraham, Keefe;; Flanigan. 1990. American Democracy: Institutions, Politics, and Policies. New York: Harper \& Row Publisher.

Adolf, Huala. 2002, Aspek-Aspek Nagara Dalam Hukum Internasional, Jakarta: PT.Raja Grafindo Persada. 
Agastya ABM, M.. 2013. Arab Spring: Badai Revolusi Timur Tengah yang Penuh Darah. Jogjakarta: IRCiSoD.

Anderson, Nicholas D. 2012. Re-redefining International Security, The Josef Korbel Journal of Advanced International Studies -Summer, Georgetown University,

Browers, Michaelle. 2009. Political Ideology in the Arab World: Accommodation and Transformation. New York: Cambridge University Press

Burchill, Scott dan Linklater, Andrew. 1996. Theories of International Relations. New York: ST Martin's Press, INC.

Buzan, Barry. 1991. People, State and Fear: An Agenda for International Security Studies in The Post Cold War Era. Second Edition, Harvester Wheatsheaf, London,.

Cipto, Bambang. 2003. Politik dan Pemerintahan Amerika. Yogyakarta: Lingkaran.

Dorsey, James M.. 2013. The US Bogeyman in Post-coup Egypt. Singapura: S. Raja Ratnam School of International Studies.

Holsti, K.J. 1992. International Politics, A Framework for Analysis: Sixth Edition, New Jersey: Prentice-Hall International Editions.

Husaini, Adian. 2005. Wajah Peradaban Barat. Jakarta: Gema Insani.

Keohane, Robert O. \& J. L. Holzgrefe, ed, 2003, Humanitarian Intervention: Ethical, Legal, and Political Dilemmas, Cambridge University Press.

Mansbach, Richard W. dan Rafferty, Kirsten L.. 2008. Introduction to Global Politics, New York: Routledge.

Marshall, Catherine dan Rossman, Gretchen B. 1994 Designing Qualitative Research 2nd Edition. California: Sage Publication.

Mauna, Boer. 2005, Hukum Internasional: Pengertian, Peranan dan Fungsi Dalam Era Dinamika Global, Edisi ke-2, Bandung: PT.Alumni.

Minderop, Albertine. 2006. Pragmatisme: Sikap Hidup dan Prinsip Politik Luar Negeri Amerika. Jakarta: Yayasan Obor Indonesia.

Orlando, Christopher; Mawson, Sylvester. 1962. Roget's International Thesaurus. Crowell.

Perwita, Anak Agung Banyu dan Yani, Yanyan Mochamad. 2005 Pengantar IImu Hubungan Internasional, Remaja Rosda Karya, Bandung.

Phares, Walid. 2010. Coming Revolution: Struggle for Freedom in the Middle East. New York: Simon \& Schuster.

Posusney, Marsha Pripstein; Angrist, Michele Penner, ed. 2005. Authoritarianism in the Middle East: Regimes and Resistance. Boulder: Lynne Rienner

Robert F.Barsky. 1997. Noam Chomsky: A Life of

Dissent. Cambridge, MA: MIT Press

Rourke, J.T. 2003. International Politics on the World Stage. New York: McGraw-Hill/Dushkin.

Sayigh, Yazid. 2012. Above The State: The Officers' Republic in Egypt. Carnegie Endowment.

Spawforth, A; Hornblower, S.,. (Eds). 1998. The Oxfrod Companion to Classical Civilization.

Tauber, Lilian. 2013. American Values vs. Foreign Policy Interests in Egypt. New York: Sweet Briar College Honors Summer Research.

Vivienne, Jabri. 2008. Reflections on the Study of International Relations, dalam Trevor Salmon,. dan Mark F. I., Issues in International Relations (Second Edition), New York: Routledge.

Wallesce, Sayre. 1977. American Government. New York: Barnes \&
Noble, Inc,

Dokumen Resmi

Daily Briefing by Press Secretary Jay Carney. terdapat di: http:// www.whitehouse.gov/the-press-office/2013/07/09/daily-briefingpress-secretary-jay-carney-07092013 Diakses pada 16 Maret 2014 pukul 12.50 WIB.

U.S. DEPARTMENT OF STATE Office of the Spokesperson STATEMENT BY SECRETARY KERRY Situation in Egypt terdapat di: http:// Iondon.usembassy.gov/midest334.html Diakses pada 16 Maret 2014 pukul 12.54 WIB

Uni Arab Emirates Ministry of Foreign Affairs Official Website. http:// www.mofa.gov.ae/mofa_english/portal/73f0d172-821e-4a99-babfd7c11 bb361 c7.aspx Diakses pada 23 Oktober 2014 pukul 20.28 WIB

US Departemen of Defense. Bright Star Stoppage Signals U.S. Objection to Violence in Egypt. http://www. defense.gov/news/ newsarticle.aspx? $\mathrm{id}=120638$ Diakses pada 6 April 2014 pukul 14.14 WIB.

Whitehouse Official Website. http://www.whitehouse.gov/the-pressoffice/2013/07/09/daily-briefing-press-secretary-jay-carney07092013 Diakses pada 6 April 2014 pukul 12.50 WIB.

Situs Web

"Egypt Ambassador: Suleiman "De Facto Head of State" - World Watch". CBS News. http://www.cbsnews.com/8301-503543 16220031433-503543.html. Diakses 28 Oktober 2014 pukul 23.26 WIB.

Al Jjazeera English, Saudi king backs Egypt's military, 17 Agustus 2013. http://www.aljazeera.com/news/middleeast/2013/08/ 201381615196784361. html diakses 23 Oktober 2014 Pukul 19:48 Jonahon Burch. Turkey's Erdogan slams world's 'double standards' on Egypt. http://www.reuters.com/article/2013/07/19/us-egyptprotests-turkey-idUSBRE96IONJ20130719. Diakses pada 6 April 2014 pukul 13.51 WIB.

Karin Laub (8 September 2011). "Libyan estimate: At least 30,000 died in the war". San Francisco Chronicle. Associated. Press terdapat di: http://www.sfgate.com/cgibin/article.cgi?f=/n/a/2011/09/08/ international/i004907D85.DTL

Londoño, Ernesto. U.s. To Partially Resume Military Aid to Egypt. http:/ /www.washingtonpost.com/world/national-security/us-to-partiallyresume-military-aid-to-egypt/2014/04/22/b25f68c6-ca91-11e393eb-6c0037dde2ad_story.html diakses pada 26 Oktober 2014 pukul 14.40 WIB.

Morsy out in Egypt coup". CNN. 28 June 2013. Terdapat di: http:// www.cnn.com/2013/07/03/world/meast/egypt-protests/ index.html?hpt=hp_t1 Diakses pada 16 Maret 2014 pukul 13.34 WIB.

Turkey's Erdogan slams world's 'double standards' on Egypt terdapat di: http://www.reuters.com/article/2013/07/19/us-egypt-proteststurkey-idUSBRE96IONJ20130719. Diakses pada 16 Maret 2014 pukul 13.51 WIB

Wall Street Journal Live. 2013. Obama and the Muslim BrotherhoodUS President Denies Taking Sides in Egypt Coup Crisis. Dapat diakses di: WSJDIgitalNetwork. http://www.youtube.com/watch?v=M5HoVjUUJc diakses pada 18 Maret 2014 pukul 22.05 WIB.

Wikithawra. http://wikithawra.wordpress.com/2013/12/31/report2013/ Diakses pada 23 oktober 2014 pukul 23.32 WIB 